\title{
TINGKAT KECEMASAN RADIOGRAFER DALAM MEMBERIKAN PELAYANAN RADIOLOGI PADA MASA PANDEMI COVID-19 DI RUMAH SAKIT BAITUL HIKMAH KENDAL
}

\author{
Indah Sulistyowati ${ }^{*}$, Lucky Restyanti Wahyu Utami \\ 1 Universitas Widya Husada Semarang \\ Email : indahs_17610@yahoo.com*, lucky.restyanti@gmail.com
}

Diterima : 5 April 2021 . Disetujui : 15 Juli 2021 . Dipublikasikan : 28 Juli 2021

\begin{abstract}
ABSTRAK
Salah satu tenaga kesehatan yang berperan sebagai garda terdepan dalam wabah Covid-19 adalah radiografer. Pemeriksaan radiologi yang digunakan untuk menunjang diagnosa corona virus disease 2019 diantaranya adalah pemeriksaan foto thorax dan CT scan thorax. Faktor psikologis yang dialami oleh tenaga kesehatan disaat pandemi corona virus disease 2019 memunculkan kecemasan mengenai kesehatan diri sendiri dan keluarga. Dampak kecemasan yang dialami oleh tenaga kesehatan dapat berpotensi mengganggu bahkan sampai mematikan pelayanan kesehatan dan akan mempengaruhi penanganan pandemi Covid-19. Tujuan penelitian ini untuk mengetahui Tingkat Kecemasan Radiografer Dalam Memberikan Pelayanan Radiologi Pada Masa Pandemi Covid-19 Di Rumah Sakit Baitul Hikmah Kendal.

Jenis penelitian yang digunakan adalah penelitian deskriptif dengan tujuan untuk mendiskripsikan atau menggambarkan fakta-fakta mengenai populasi secara sistematis, dan akurat. Populasi dalam penelitian ini adalah semua radiografer di Rumah Sakit Baitul Hikmah Kendal. Sampel dalam penelitian ini adalah semua radiografer di Rumah Sakit Baitul Hikmah Kendal sejumlah 4 orang. Variabel yang digunakan dalam penelitian ini adalah Tingkat Kecemasan Radiografer Dalam Memberikan Pelayanan Radiologi Pada Masa Pandemi Covid-19. Pengumpulan data menggunakan kuesioner Zung-Self Anxiety Rating Scale (ZSAS). Analisa data menggunakan analisis univariat yang menghasilkan distribusi dan persentase dari tiap variabel.

Dari hasil penelitian didapatkan bahwa seluruh responden tidak ada kecemasan dalam memberikan pelayanan radiologi pada masa pandemi Covid-19 yaitu sebanyak 4 orang $(100 \%)$ dengan skor masing-masing 28 , 29, 37 dan 44 berdasarkan kuesioner Zung-Self Anxiety Rating Scale (ZSAS). Saran yang dapat diberikan adalah perlunya dukungan dari berbagai pihak baik pimpinan, keluarga dan sesama tenaga kesehatan tak terkecuali diri sendiri untuk dapat mengurangi tingkat kecemasan radiografer sebagai salah satu garda terdepan dalam mengahadapi wabah Covid 19.
\end{abstract}

Kata kunci : tingkat kecemasan, pelayanan radiologi, covid-19

\section{ABSTRACT}

One of the health workers who acts as the front line in the Covid-19 outbreak is a radiographer. Radiological examinations used to support the diagnosis of corona virus disease 2019 include examination of thorax photos and CT scans of the thorax. Psychological factors experienced by health workers during the 2019 corona virus disease pandemic raised anxiety about the health of themselves and their families. The impact of anxiety experienced by health workers can potentially disrupt and even turn off health services and will affect the handling of the Covid-19 pandemic. The purpose of this study was to determine the level of radiographer's anxiety in providing radiology services during the Covid-19 pandemic at Baitul Hikmah Kendal Hospital.

The type of research used is descriptive research with the aim of describing or describing facts about the population systematically and accurately. The population in this study were all radiographers at Baitul Hikmah Kendal Hospital. The sample in this study were all 4 radiographers at Baitul Hikmah Kendal Hospital. The variable used in this study is the Radiographer's Level of Anxiety in Providing Radiological Services During the Covid-19 Pandemic. Collecting data using the Zung-Self Anxiety Rating Scale (ZSAS) questionnaire. Data analysis used univariate analysis which resulted in the distribution and percentage of each variable.

From the results of the study, it was found that all respondents had no anxiety in providing radiology services during the Covid-19 pandemic, namely 4 people (100\%) with scores of 28, 29, 37 and 44 respectively based on the Zung-Self Anxiety Rating Scale (ZSAS) questionnaire. ). The advice that can be given is the need for support from various parties, both leaders, families and fellow health workers, including yourself, to be able to reduce the level of anxiety of the radiographer as one of the front lines in dealing with the Covid 19 outbreak.

Keywords: anxiety level, radiology service, covid-19 


\section{PENDAHULUAN}

Corona virus disease 2019 merupakan virus RNA strain tunggal positif, berkapsul dan tidak bersegmen yang menginfeksi saluran pernafasan (PDPI, 2020). Gejala umum yang dirasakan pada penderita corona virus disease 2019 yaitu berupa demam, batuk dan kesulitan bernafas (Yuliana, 2020).

Corona virus disease 2019 dikonfirmasi dapat menular dari manusia ke manusia melalui transmisi pneumonia (Relman, 2020). Virus ini dapat menyebabkan kematian terhadap penderitanya. Kasus kematian akibat corona virus disease 2019 ini banyak dialami oleh orang tua dan pasien yang disertai dengan peyakit penyerta (The Straits Time, 2020).

Dalam pandemi corona virus disease 2019 yang sedang terjadi saat ini, tenaga kesehatan mempunyai peranan sebagai garda terdepan dalam mendiagnosa dan mengobati penderita (Cheng et al., 2020). Salah satu tenaga kesehatan yang berperan sebagai garda terdepan dalam wabah ini ialah radiografer, yaitu dengan melakukan pemeriksaan penunjang radiologi. Pemeriksaan radiologi yang digunakan untuk menunjang diagnosa corona virus disease 2019 diantaranya adalah pemeriksaan foto thorax dan CT scan thorax (Yuliana, 2020).

Faktor psikologis yang dialami oleh tenaga kesehatan disaat pandemi corona virus disease 2019 memunculkan kecemasan mengenai kesehatan diri sendiri dan keluarga (Cheng et al., 2020). Kontak petugas kesehatan yang sering dengan pasien dengan corona virus disease 2019, tanpa alat pelindung diri (APD) yang tepat atau APD yang tidak sesuai standar kesehatan merupakan sumber ketakutan, stres, dan kecemasan yang mendalam. Sebagian besar dari tenaga kesehatan sudah mengalami, dan akan mengalami, beberapa kesulitan fisik dan psikologis yang melampaui kapasitas mereka.

Kecemasan merupakan rasa khawatir yang dirasakan oleh seseorang dengan perasaan yang tidak berdaya dan tidak pasti (Stuart, 2016). Kecemasan adalah perasaan takut yang tidak jelas dan tidak didukung oleh situasi. Gangguan kecemasan merupakan kondisi yang menggambarkan adanya kecemasan yang berlebihan, disertai respon perilaku, emosional dan fisiologis (Amir, 2013). Dampak kecemasan yang dialami oleh tenaga kesehatan dapat berpotensi mengganggu bahkan sampai mematikan pelayanan kesehatan dan akan mempengaruhi penanganan pandemi covid-19 (Handayani, 2020).

Berdasarkan paparan diatas, maka penulis tertarik melakukan penelitian dengan judul "Tingkat Kecemasan Radiografer Dalam Memberikan Pelayanan Radiologi Pada Masa Pandemi Covid-19 Di Rumah Sakit Baitul Hikmah Kendal".

Tujuan Mengetahui Tingkat Kecemasan Radiografer Dalam Memberikan Pelayanan Radiologi Pada Masa Pandemi Covid-19 Di Rumah Sakit Baitul Hikmah Kendal.

\section{METODE PENELITIAN}

Jenis penelitian yang digunakan adalah penelitian deskriptif yang dilakukan dengan tujuan untuk mendiskripsikan atau menggambarakan faktafakta mengenai populasi secara sistematis, dan akurat.

Populasi dalam penelitian ini adalah semua radiografer di Rumah Sakit Baitul Hikmah Kendal. Sampel dalam penelitian ini adalah semua radiografer di Rumah Sakit Baitul Hikmah Kendal sejumlah 4 orang. Dalam penelitian ini teknik sampling yang digunakan adalah teknik sampling jenuh, yaitu teknik menentukan sampel bila semua anggota populasi digunakan sebagai sampel.

Variabel dalam penelitian ini adalah Tingkat Kecemasan Radiografer Dalam Memberikan 
Pelayanan Radiologi Pada Masa Pandemi Covid-19. Secara operasional, variabel tersebut didefinisikan dan diukur dengan cara sebagai berikut.

Kecemasan merupakan kondisi emosi dengan timbulnya rasa tidak nyaman pada diri seseorang dan merupakan pengalaman yang samar-samar disertai dengan perasaan yang tidak berdaya serta tidak menentu yang disebabkan oleh suatu hal yang belum jelas.

Untuk mengukur variabel tersebut digunakan kuesioner Zung-Self Anxiety Rating Scale (ZSAS) dengan jumlah pertanyaan 20 soal. Dengan kategori yaitu skor 20-44 normal/ tidak ada kecemasan; skor 45-59 kecemasan ringan; skor 60-74 kecemasan sedang; skor 75-80 kecemasan berat. Skala yang digunakan adalah skala ordinal.

Dalam penelitian ini, data primer diperoleh secara langsung dari responden dengan menggunakan kuesioner Zung-Self Anxiety Rating Scale (ZSAS) yang berisi pertanyaan Tingkat Kecemasan Radiografer Dalam Memberikan Pelayanan Radiologi Pada Masa Pandemi Covid-19.
Data sekunder pada penelitian ini diperoleh dari Rumah Sakit Baitul Hikmah Kendal.

Dari data yang terkumpul selanjutnya dianalisis dengan menggunakan analisis univariat yaitu dilakukan pada variabel Tingkat Kecemasan Radiografer Dalam Memberikan Pelayanan Radiologi Pada Masa Pandemi Covid-19. Dalam analisis ini hanya menghasilkan distribusi dan persentase dari tiap variabel. Hasil persentase dari tiap variabel tersebut disusun dalam bentuk tabel univariat yaitu suatu tabel yang menggambarkan penyajian data untuk tiap variabel saja (Budiarto, 2002; h. 37).

\section{HASIL DAN PEMBAHASAN}

Hasil penelitian pada analisis univariat disajikan dalam bentuk tabel distribusi frekuensi, sebagaimana diuraikan secara ringkas di bawah ini. Tabel 1, 2 dan 3 menyajikan data tentang karakteristik responden, Tabel 4 menyajikan data tentang tingkat kecemasan responden dan Tabel 5 menyajikan data tentang hasil dari Zung Self-rating Anxiety Scale (ZSAS).

Tabel 1

Distribusi Frekuensi Responden Berdasarkan Jenis Kelamin

\begin{tabular}{lcc}
\hline \multicolumn{1}{c}{ Jenis kelamin } & Frekuensi & Persentase \\
\hline Laki-Laki & 2 & $50 \%$ \\
Perempuan & 2 & $50 \%$ \\
\hline \multicolumn{1}{c}{ Jumlah } & 4 & 100 \\
\hline
\end{tabular}

Dari Tabel 1 menunjukkan bahwa sebagian responden berjenis kelamin perempuan dan sebagian berjenis kelamin laki-laki yaitu sebanyak 2 orang (50\%).

Tabel 2

Distribusi Frekuensi Responden Berdasarkan Status Pernikahan

\begin{tabular}{|c|c|c|}
\hline Status Pernikahan & Frekuensi & Persentase \\
\hline Tidak Menikah & 0 & $0 \%$ \\
\hline Menikah & 4 & $100 \%$ \\
\hline Jumlah & 0 & 100 \\
\hline
\end{tabular}


Dari Tabel 2 menunjukkan bahwa semua respoden sudah menikah yaitu sebanyak 4 orang $(100 \%)$.

Tabel 3

Distribusi Frekuensi Responden Berdasarkan Usia

\begin{tabular}{cccc}
\hline & Usia & Frekuensi & Persentase \\
\hline $20-35$ & & 4 & $100 \%$ \\
Lebih dari 35 & & 0 & $0 \%$ \\
\hline \multicolumn{2}{r}{ Jumlah } & 4 & 100 \\
\hline
\end{tabular}

Dari Tabel 3 menunjukkan bahwa semua respoden berada pada kategori usia 20-35 tahun yaitu sebanyak 4 orang (100\%).

Tabel 4

Distribusi Frekuensi Responden Berdasarkan Tingkat Kecemasan

\begin{tabular}{lcc}
\hline \multicolumn{1}{c}{ Tingkat Kecemasan } & Frekuensi & Persentase \\
\hline Tidak Ada Kecemasan & 4 & $100 \%$ \\
Kecemasan Ringan & 0 & $0 \%$ \\
Kecemasan Sedang & 0 & $0 \%$ \\
Kecamasan Berat & 0 & $0 \%$ \\
\hline \multicolumn{1}{c}{ Jumlah } & 4 & 100
\end{tabular}

Dari Tabel 4 menunjukkan bahwa seluruh responden radiologi pada masa pandemi Covid-19 yaitu sebanyak tidak ada kecemasan dalam memberikan pelayanan 4 orang $(100 \%)$.

Tabel 5

Distribusi Frekuensi Responden Berdasarkan Berdasarkan Zung Self-rating Anxiety Scale (ZSAS)

\begin{tabular}{clcccccccc}
\hline No & \multicolumn{1}{c}{ Pernyataan } & \multicolumn{2}{c}{ Jarang } & \multicolumn{2}{c}{ Kadang } & \multicolumn{2}{c}{ Sering } & \multicolumn{2}{c}{ Selalu } \\
\hline & \multicolumn{1}{c}{ Frek } & $\%$ & Frek & $\%$ & Frek & $\%$ & Frek & $\%$ \\
\hline 1 & $\begin{array}{l}\text { Saya merasa lebih gugup dan } \\
\text { cemas dari biasanya }\end{array}$ & 1 & $25 \%$ & 3 & $75 \%$ & 0 & $0 \%$ & 0 & $0 \%$ \\
\hline 2 & $\begin{array}{l}\text { Saya merasa takut tanpa } \\
\text { alasan }\end{array}$ & 1 & $25 \%$ & 2 & $50 \%$ & 1 & $25 \%$ & 0 & $0 \%$ \\
\hline 3 & $\begin{array}{l}\text { Saya mudah marah atau } \\
\text { merasa panik }\end{array}$ & 1 & $25 \%$ & 2 & $50 \%$ & 1 & $25 \%$ & 0 & $0 \%$ \\
\hline 4 & $\begin{array}{l}\text { Saya merasa seperti tak } \\
\text { berdaya }\end{array}$ & 2 & $50 \%$ & 2 & $50 \%$ & 0 & $0 \%$ & 0 & $0 \%$ \\
\hline 5 & $\begin{array}{l}\text { Saya merasa baik-baik saja } \\
\text { dan tidak ada sesuatu yang } \\
\text { buruk akan terjadi }\end{array}$ & 0 & $0 \%$ & 2 & $50 \%$ & 2 & $50 \%$ & 0 & $0 \%$ \\
\hline 6 & $\begin{array}{l}\text { Tangan dan kaki saya } \\
\text { gemetar akhir-akhir ini }\end{array}$ & 3 & $75 \%$ & 1 & $25 \%$ & 0 & $0 \%$ & 0 & $0 \%$ \\
\hline 7 & $\begin{array}{l}\text { Saya merasa terganggu } \\
\text { dengan sakit kepala, leher } \\
\text { dan nyeri punggung }\end{array}$ & $25 \%$ & 2 & $50 \%$ & 1 & $25 \%$ & 0 & $0 \%$ \\
\hline 8 & $\begin{array}{l}\text { Saya merasa lemah dan } \\
\text { cepat lelah }\end{array}$ & $25 \%$ & 2 & $50 \%$ & 1 & $25 \%$ & 0 & $0 \%$ \\
\hline 9 & $\begin{array}{l}\text { Saya merasa tenang dan } \\
\text { dapat duduk dengan santai }\end{array}$ & 1 & $25 \%$ & 2 & $50 \%$ & 1 & $25 \%$ & 0 & $0 \%$ \\
\hline
\end{tabular}




\begin{tabular}{|c|c|c|c|c|c|c|c|c|c|}
\hline 10 & $\begin{array}{l}\text { Saya merasa jantung saya } \\
\text { berdetak sangat cepat }\end{array}$ & 2 & $50 \%$ & 2 & $50 \%$ & 0 & $0 \%$ & 0 & $0 \%$ \\
\hline 11 & $\begin{array}{lll}\text { Saya } & \text { terganggu } \\
\text { pusing } & & \\
\end{array}$ & 1 & $25 \%$ & 3 & $75 \%$ & 0 & $0 \%$ & 0 & $0 \%$ \\
\hline 12 & $\begin{array}{l}\text { Saya pingsan atau merasa } \\
\text { seperti mau pingsan }\end{array}$ & 4 & $100 \%$ & 0 & $0 \%$ & 0 & $0 \%$ & 0 & $0 \%$ \\
\hline 13 & $\begin{array}{l}\text { Saya dapat bernapas dengan } \\
\text { mudah }\end{array}$ & 2 & $50 \%$ & 1 & $25 \%$ & 1 & $25 \%$ & 0 & $0 \%$ \\
\hline 14 & $\begin{array}{l}\text { Saya merasa mati rasa dan } \\
\text { kesemutan di jari tangan dan } \\
\text { jari kaki }\end{array}$ & 3 & $75 \%$ & 1 & $25 \%$ & 0 & $0 \%$ & 0 & $0 \%$ \\
\hline 15 & $\begin{array}{l}\text { Saya merasa perut saya } \\
\text { terganggu }\end{array}$ & 2 & $50 \%$ & 2 & $50 \%$ & 0 & $0 \%$ & 0 & $0 \%$ \\
\hline 16 & Saya sering kencing & 1 & $25 \%$ & 2 & $50 \%$ & 1 & $25 \%$ & 0 & $0 \%$ \\
\hline 17 & $\begin{array}{l}\text { Tangan saya kering dan } \\
\text { hangat }\end{array}$ & 1 & $25 \%$ & 2 & $50 \%$ & 1 & $25 \%$ & 0 & $0 \%$ \\
\hline 18 & $\begin{array}{l}\text { Wajah saya terasa panas dan } \\
\text { kemerahan }\end{array}$ & 3 & $75 \%$ & 0 & $0 \%$ & 1 & $25 \%$ & 0 & $0 \%$ \\
\hline 19 & $\begin{array}{l}\text { Saya dapat tidur dengan } \\
\text { mudah }\end{array}$ & 2 & $50 \%$ & 1 & $25 \%$ & 1 & $25 \%$ & 0 & $0 \%$ \\
\hline 20 & Saya mengalami mimpi buruk & 2 & $50 \%$ & 2 & $50 \%$ & 0 & $0 \%$ & 0 & $0 \%$ \\
\hline
\end{tabular}

Dari Tabel 5 menunjukkan bahwa meskipun berdasarkan total skore seluruh responden tidak ada kecemasan dalam memberikan pelayanan radiologi, tetapi berdasarkan rincian pertanyaan dari Zung Selfrating Anxiety Scale (ZSAS) masih didapatkan beberapa skore yang cenderung mengarah kepada kecemasan diantaranya dalam menjawab pertanyaan ke-5 yaitu saya merasa baik-baik saja dan tidak ada sesuatu yang buruk akan terjadi 50\% menjawab kadang-kadang, dalam pertanyaan ke-9 yaitu saya merasa tenang dan dapat duduk dengan santai $25 \%$ responden menjawab jarang dan 50\% menjawab kadang-kadang, dalam pertanyaan ke-13 yaitu saya dapat bernapas dengan mudah $50 \%$ responden menjawab jarang dan 25\% menjawab kadang-kadang, sedangkan dalam pertanyaan ke-19 yaitu saya dapat tidur dengan mudah 50\% responden menjawab jarang dan 25\% menjawab kadang-kadang.

Dari analisis univariat didapatkan hasil bahwa seluruh responden tidak ada kecemasan dalam memberikan pelayanan radiologi pada masa pandemi covid-19. Tetapi meskipun berdasarkan total skore seluruh responden tidak ada kecemasan dalam memberikan pelayanan radiologi, tetapi berdasarkan rincian pertanyaan dari Zung Self-rating Anxiety Scale (ZSAS) masih didapatkan beberapa skore yang cenderung mengarah kepada kecemasan yang perlu mendapatkan perhatian khusus diantaranya adalah pada poin pertanyaan merasa baik-baik saja dan tidak ada sesuatu yang buruk akan terjadi, merasa tenang dan dapat duduk dengan santai, dapat bernapas dengan mudah dan dapat tidur dengan mudah.

Tingkat kecemasan dapat dipengaruhi oleh beberapa faktor baik internal maupun eksternal. Salah satu faktor yang dapat mempengaruhi tingkat kecemasan seseorang adalah berhubungan dengan perubahan dalam lingkungan. Dimana pada saat ini seluruh negara di dunia sedang mengalami wabah Covid 19 tidak terkecuali Indonesia.

Dengan kondisi tersebut tenaga kesehatan termasuk radiografer dituntut untuk tetap memberikan pelayanan radiologi, meskipun mereka dihadapkan dengan resiko untuk tertular virus tersebut. Dalam hal 
ini dukungan dari pimpinan, keluarga dan sesama tenaga kesehatan tak terkecuali diri sendiri sangat diperlukan untuk dapat mengurangi tingkat kecemasan radiografer sebagai salah satu garda terdepan dalam mengahadapi wabah tersebut. Serta perlunya meningkatkan kewaspadaan supaya tidak tertular dengan tetap meningkatkan protokol kesehatan saat memberikan pelayanan radiologi diantaranya pengaturan area dan petugas, persiapan pemeriksaan, pelaksanaan pemeriksaan, tingkat penggunaan APD, metode pembersihan dan desinfeksi serta penanganan limbah medis.

\section{SIMPULAN DAN SARAN}

Dari hasil penelitian didapatkan :

1. Seluruh responden tidak ada kecemasan dalam memberikan pelayanan radiologi pada masa pandemi covid-19 di RS Baitul Hikmah Kendal yaitu dengan skor masing-masing 28, 29, 37 dan 44 berdasarkan kuesioner Zung-Self Anxiety Rating Scale (ZSAS).

2. Sebagian besar responden (75\%) kadangkadang merasa lebih gugup dan cemas dari biasanya.

3. Sebagian responden (50\%) kadang-kadang merasa takut tanpa alasan.

4. Sebagian responden (50\%) kadang-kadang mudah marah atau merasa panik.

5. Sebagian responden (50\%) kadang-kadang merasa seperti tak berdaya.

6. Sebagian responden (50\%) kadang-kadang merasa baik-baik saja dan tidak ada sesuatu yang buruk akan terjadi.

7. Sebagian besar responden (75\%) jarang tangan dan kakinya gemetar akhir-akhir ini.

8. Sebagian responden (50\%) kadang-kadang merasa terganggu dengan sakit kepala, leher dan nyeri punggung.
9. Sebagian responden (50\%) kadang-kadang merasa lemah dan cepat lelah.

10. Sebagian responden (50\%) kadang-kadang merasa tenang dan dapat duduk dengan santai.

11. Sebagian responden (50\%) kadang-kadang merasa jantungnya berdetak sangat cepat.

12. Sebagian besar responden (75\%) kadangkadang terganggu karena pusing.

13. Seluruh responden (100\%) jarang pingsan atau merasa seperti mau pingsan.

14. Sebagian responden $(50 \%)$ jarang dapat bernapas dengan mudah.

15. Sebagian besar responden (75\%) jarang merasa mati rasa dan kesemutan di jari tangan dan jari kaki.

16. Sebagian responden (50\%) kadang-kadang merasa perutnya terganggu.

17. Sebagian responden (50\%) kadang-kadang sering kencing.

18. Sebagian responden (50\%) kadang-kadang tangannya kering dan hangat.

19. Sebagian besar responden (75\%) jarang wajahnya terasa panas dan kemerahan.

20. Sebagian responden $(50 \%)$ jarang dapat tidur dengan mudah.

21. Sebagian responden $(50 \%)$ kadang-kadang mengalami mimpi buruk.

Perlu dukungan dari berbagai pihak baik pimpinan, keluarga dan sesama tenaga kesehatan tak terkecuali diri sendiri untuk dapat mengurangi tingkat kecemasan radiografer sebagai salah satu garda terdepan dalam mengahadapi wabah Covid 19.

\section{DAFTAR PUSTAKA}

Amir. (2013). Buku Ajar Psikiatri Edisi ke 2. Jakarta: FKUI. 
Annisa DA, Ifdil. (2016). Konsep Kecemasan (Anxiety) pada Lanjut Usia (Lansia). Ejournal Konselor Universitas Negeri Padang. Volume 5. Nomor 2.

Cheng Q, Liang M, Li Y, He L, Guo J, Fei D, Wang L, He L, Sheng C, Cai Y, Li X, Wang J, Zhang Z. (2020). Mental Health Care for Medical Staff in China During the COVID-19 Outbreak. The Lancet Psychiatry. Volume 7. Halaman e15-e16.

Handayani RT, Suminanto, Darmayanti AT, Widiyanto A, Atmojo JT. (2020). Kondisi dan Strategi Penanganan Kecemasan Pada Tenaga Kesehatan Saat Pandemi Covid-19. Jurnal IImu Keperawatan Jiwa. Volume 3. Nomor 3.

Keputusan Menteri Kesehatan Republik Indonesia. (2008). Standar Pelayanan Radiologi Diagnostik di Sarana Pelayanan Kesehatan.

Perhimpunan Dokter Paru Indonesia (PDPI). (2020). Pneumonia Covid-19 Diagnosis dan Penatalaksanaan di Indonesia.

Safaria T, Saputra NE. (2012). Manajemen Emosi: Sebuah Panduan Cerdas Bagaimana Mengelola Emosi Positif dalam Hidup Anda. Jakarta: Bumi Aksara.

Schwartz S. (2000). Abnormal Psychology: a Discovery Approach. California: Mayfield Publishing Company.
Stuart GW. (2006). Buku Saku Keperawatan Jiwa. Alih Bahasa: Ramona P. Kapoh \& Egi Komara Yudha. Jakarta: EGC.

Stuart GW. (2016). Prinsip dan Praktik Keperawatan Kesehatan Jiwa. Singapore: Elsevier.

The Straits Times. (2020). China Reports First Death in Wuhan Pneumonia Outbreak.

Wijokongko S, Ardianto J, Fatimah, Utami AP, Rustanto, Setiyawan DA, Trisikwanto H, Sugeng D, Saputro SD. (2016). Protokol Radiologi Radiografi Konvensional, Kedokteran Nuklir, Radioterapi, CT scan dan MRI Jilid I. Magelang: Inti Medika Pustaka.

Wijokongko S, Ardianto J, Fatimah, Utami AP, Rustanto, Setiyawan DA, Trisikwanto H, Sugeng D, Saputro SD. (2016). Protokol Radiologi Radiografi Konvensional, Kedokteran Nuklir, Radioterapi, CT scan dan MRI Jilid II. Magelang: Inti Medika Pustaka.

World Health Organization (WHO). (2020). Global Surveillance for Human Infection with Novel Coronavirus (2019-nCoV).

Yuliana. (2020). Corona Virus Diseases (Covid-19); Sebuah Tinjauan Literatur. Wellness and Healthy Magazine. Volume 2. Nomor 1. 